\title{
High Sucrose Levels and Abnormal Enzyme Activity as a Function of Nutritional Stress in Sugarcane
}

\author{
Alex G. Alexander ${ }^{1}$ \\ INTRODUCTION
}

Sugarcane nutrition studies have revealed unusually high sucrose levels when nitrate $(1,2)^{2}$ and calcium $(3,14,17)$ are withheld from the plant. Such increases are sometimes attributed to "physiological stress", while the mechanisms of added sucrose accumulation remain obscure. A logical question is whether low supply of any major nutrient will yield sucrose increases. If so, are these increases caused by actual nutrient deficiency, or simply by shifts in the balance of one nutrient with another? Finally, in relation to previous sucrose-enzyme work conducted here, we are interested in learning whether sugar fluctuations caused by different nutritional treatments can be traced to common enzymatic behavior patterns consistent among all treatments.

This paper deals with sugarcane experiments in which deficiencies of $\mathrm{NO}_{3},{ }^{3} \mathrm{P}, \mathrm{K}$, and $\mathrm{Ca}$ were gradually induced over a prolonged period. There were three objectives: 1 , To determine whether high sucrose can be obtained by withholding a series of major nutrients; 2 , to determine whether actual deficiency is required of a given nutrient to induce sugar changes; and 3, to ascertain whether increased sucrose production can be traced to common behavior patterns of hydrolytic and oxidative enzymes.

\section{MATERIALS AND METHODS}

Deficiencies of N, P, K, and Ca were induced gradually among plants grown in sand culture. One-eye cuttings of the variety M. 336 were planted in "silica shot", previously washed with $0.01 N \mathrm{HCl}$, and contained in glazed, 2-gallon pots with glass wool over the drainage outlets. All seedlings received 1 liter of a complete nutrient solution until 14 weeks of age. ${ }^{4}$ At that time the plants were arranged in five groups. One group, serving as the control, continued to receive the complete nutrient solution. Another group received stepwise reductions of nitrate, a third received gradually

${ }^{1}$ Associate Plant Physiologist, Agricultural Experiment Station, Mayagüez Campus, University of Puerto Rico, Río Piedras, P.R.

${ }^{2}$ Italic numbers in parenthesis refer to Literature Cited, pp 332-3.

${ }^{3}$ Nitrate, $\left(\mathrm{NO}_{3}\right)$.

${ }^{4}$ Nutrient concentrations, expressed as meq./liter, were provided as follows: Nitrate, 16; P, 15; K, 11; Ca, 6; magnesium, 2; and sulfur, 2. Microelements, expressed as p.p.m., were given as follows: Iron, 1.5 ; boron, 0.05 ; copper, 0.02 ; zinc, 0.02 ; manganese, 0.50 ; and molybdenum, 0.01 . 
lessened P, etc. Table 1 summarizes the nutrient levels supplied over a treatment period of 16 weeks.

Samples were harvested at 14 weeks, just prior to initial treatments, and subsequent harvests were made at the completion of each 2-week treatment interval. Leaves +1 to +4 were frozen in a mixture of Dry Ice and acetone, lyophilized, and ground in the cold to pass a 60-mesh screen.

Samples of the freeze-dried powder were extracted for sugar and enzyme analyses, as described previously (1). Total ketose was measured colorimetrically by the method of Roe (16), and sucrose by the technique of Cardini et al. (15). Phosphatase procedures were described earlier (5), as were those for amylase (6), polyphenol oxidase ( 7$)$, and peroxidase (8). Protein was determined by the method of Sutherland et al. (18), and enzyme

TABLE 1.-Decreasing nutrient concentrations supplied to sugarcane in sand culture ${ }^{1}$

\begin{tabular}{|c|c|c|c|c|c|c|c|c|c|}
\hline \multirow{2}{*}{ Nutrient } & \multicolumn{9}{|c|}{ Levels applied to cane aged (weeks) } \\
\hline & $0-14$ & $14-16$ & $16-18$ & $18-20$ & $20-22$ & $22-24$ & $24-26$ & $26-28$ & $28-30$ \\
\hline $\mathrm{NO}_{3}$ & 16 & 12 & 9 & 6 & 3 & 1 & 0 & 0 & 0 \\
\hline $\mathrm{P}$ & 15 & 12 & 6 & 3 & 1 & 0 & 0 & 0 & 0 \\
\hline $\mathrm{K}$ & 11 & 8 & 5 & 2 & 1 & 0 & 0 & 0 & 0 \\
\hline $\mathrm{Ca}$ & 6 & 4 & 2 & 1 & 0 & 0 & 0 & 0 & 0 \\
\hline
\end{tabular}

${ }^{1}$ Control plants received the 0 to 14 -week nutrient levels throughout the study.

action was computed as specific activity (activity units per milligram of protein).

\section{RESULTS AND DISCUSSION}

\section{LEAF SUCROSE $v s$. NUTRITIONAL STRESS}

Each group of plants subjected to nutritional stress accumulated notably higher leaf sucrose than did control plants (table 2). The low- $\mathrm{NO}_{3}$ and low-Ca treatments yielded the greatest sucrose increases. Thus it appears that nutritional stress in general will result in sugar increases.

It is important to note that absolute deficiency of the respectiva nutrients was not required to induce an upward sucrose trend. By the third harvest, at 18 weeks, the sucrose increases were already evident, although nutrient supply was still fully adequate for normal cane growth. True deficiency was not anticipated for any nutrient before 22 weeks. In fact, Nitrogen-deficiency symptoms were not observed until 25 weeks, Cadeficiency symptoms not before 27 to 28 weeks, while P- and K-deficiency symptoms were not observed at all. 
It is evident then that high sucrose is not an expression of deficiency status. Rather, an imbalance of the respective nutrient with others held constant seems to have triggered the sugar changes. These plants must have committed themselves during the first 14 weeks to the relatively high and apparently constant nutrient supply, and were greatly disturbed biochemically when reduced to levels in themselves not yet especially low. This observation is particularly important in that a mechanism of increased sucrose production can be triggered without the severe nutrient deficiencies which would ultimately reduce tonnage.

TABLE 2.-Mean values for leaf sucrose content (milligrams per gram of dry weight) of immature sugarcane supplied with decreasing concentrations of nitrate, phosphorus, potassium, and calcium in sand culture ${ }^{1}$

\begin{tabular}{|c|c|c|c|c|c|c|c|c|c|c|}
\hline \multirow{2}{*}{ Treatment } & \multicolumn{9}{|c|}{ Results with cane aged (weeks) - } & \multirow{2}{*}{ Mean } \\
\hline & 14 & 16 & 18 & 20 & 22 & 24 & 26 & 28 & 30 & \\
\hline Control & 69 & 53 & 89 & 96 & 89 & 82 & 76 & 80 & 90 & 80 \\
\hline$-\mathrm{NO}_{3}$ & 65 & 75 & 97 & 148 & 116 & 112 & 135 & 123 & 110 & 109 \\
\hline$-\mathrm{P}$ & 67 & 68 & 101 & 132 & 96 & 84 & 78 & 120 & 110 & 95 \\
\hline$-\mathrm{K}$ & 59 & 65 & 94 & 114 & 111 & 115 & 104 & 108 & 117 & 99 \\
\hline$-\mathrm{Ca}$ & 65 & 70 & 113 & 125 & 94 & 87 & 90 & 119 & 141 & 100 \\
\hline Mean & 65 & 66 & 98 & 123 & 101 & 96 & 77 & 110 & 114 & \\
\hline
\end{tabular}

${ }^{1}$ Each figure represents the computed mean of 3 replicates.

ENZYME ACTIVITY $v s$. NUTRITIONAL STRESS

Early work here with cane enzymes revealed a marked suppression of amylase and phosphatase among plants receiving low nitrate supply (1). Sucrose concurrently increased as enzyme action was lessened. With regard to amylase, it has since been concluded that its suppression reflects a reduced capacity of the plant to form starch $(4,9,6,2)$, thereby permitting a greater utilization of UDPG and glucose-1-phosphate for sucrose synthesis. The present study confirms that an important sucrose-amylase relationship exists. Whereas low nitrate caused the greatest amylase suppression, each of the nutritional treatments likewise suppressed amylase while causing increased sucrose (table 3). For $\mathrm{NO}_{3}, \mathrm{P}$, and $\mathrm{Ca}$ the amylase decline was evident at 18 weeks, or in other words before any great stress could have been imposed (fig. 1). Low $\mathrm{K}$ was also affecting amylase by 20 weeks. Low amylase action thus appears to be a common denominator for whatever sucrose mechanisms were involved in increased production.

The same cannot be said for phosphatase. The fact that suppressed phosphatase does accompany high sucrose is well documented $(1,2,10,11)$, 
TABLE 3.-Mean specific-activity values for leaf amylase of immature sugarcane supplied with decreasing nitrate, phosphorus, potassium, and calcium in sand culdure ${ }^{1}$

\begin{tabular}{|c|c|c|c|c|c|c|c|c|c|c|}
\hline \multirow{2}{*}{ Treatment } & \multicolumn{9}{|c|}{ Results with cane aged (weeks) - } & \multirow{2}{*}{ Mean } \\
\hline & 14 & 16 & 18 & 20 & 22 & 24 & 26 & 28 & 30 & \\
\hline Control & 146 & 165 & 261 & 333 & 295 & 348 & 492 & 472 & 423 & 326 \\
\hline$-\mathrm{NO}_{3}$ & 134 & 112 & 164 & 187 & 116 & 104 & 52 & 42 & 98 & 112 \\
\hline$-\mathrm{P}$ & 123 & 134 & 145 & 139 & 112 & 141 & 87 & 103 & 113 & 122 \\
\hline$-\mathrm{K}$ & 167 & 176 & 345 & 293 & 194 & 196 & 194 & 229 & 182 & 219 \\
\hline$-\mathrm{Ca}$ & 120 & 180 & 209 & 209 & 160 & 185 & 128 & 149 & 117 & 162 \\
\hline Mean & 138 & 153 & 225 & 232 & 175 & 195 & 191 & 199 & 187 & \\
\hline
\end{tabular}

${ }^{1}$ Each figure represents the computed mean of 3 replicates.

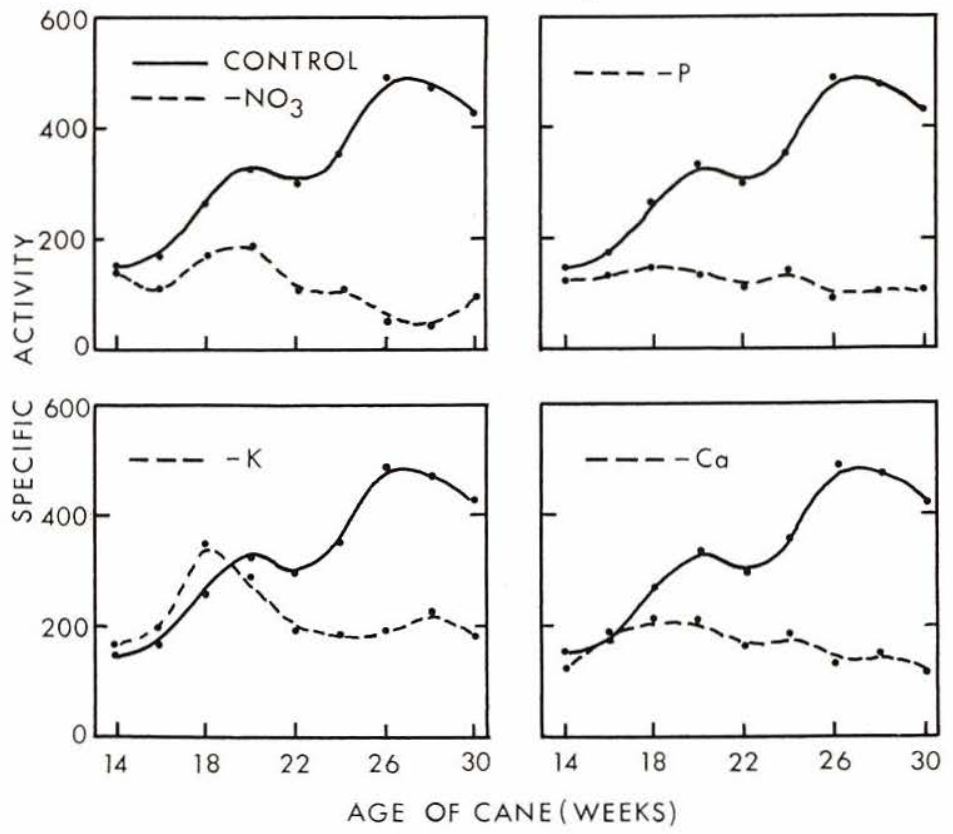

Figure 1.-Amylase decline in leaves of sugarcane supplied with decreasing levels of nitrate, phosphorus, potassium, and calcium in sand culture.

yet during the present study only two of the four nutritional treatments caused phosphatase to decline while sucrose increased. Decreasing $\mathrm{NO}_{3}$ and $\mathrm{P}$ initiated downward trends for phosphatase at around 22 weeks (table 4). Only at 30 weeks was the enzyme affected by $\mathrm{Ca}$, and it was not affected 
by $\mathrm{K}$ at all. It has been suggested that a decline of phosphatase action will permit a greater accumulation of phosphorylated sucrose precursors, thereby permitting a greater sucrose synthesis than was otherwise possible.

TABLE 4.-Mean specific-activity values for phosphatase from leaves of immature sugarcane, supplied with decreasing nitrate, phosphorus, potassium, and calcium in sand culture ${ }^{1}$

\begin{tabular}{|c|c|c|c|c|c|c|c|c|c|c|}
\hline \multirow{2}{*}{ Treatment } & \multicolumn{9}{|c|}{ Results with cane aged (weeks) - } & \multirow{2}{*}{ Mean } \\
\hline & 14 & 16 & 18 & 20 & 22 & 24 & 26 & 28 & 30 & \\
\hline Control & 10.3 & 9.4 & 15.0 & 13.7 & 13.0 & 15.8 & 14.6 & 12.6 & 13.6 & 13.1 \\
\hline$-\mathrm{NO}_{3}$ & 19.6 & 15.0 & 18.8 & 17.2 & 12.7 & 9.8 & 4.9 & 3.6 & 7.7 & 12.1 \\
\hline$-\mathrm{P}$ & 12.9 & 13.9 & 14.1 & 12.4 & 9.7 & 12.0 & 7.9 & 7.4 & 6.6 & 10.8 \\
\hline$-\mathrm{K}$ & 16.9 & 15.4 & 21.6 & 17.0 & 15.0 & 14.8 & 14.4 & 12.7 & 12.3 & 15.6 \\
\hline$-\mathrm{Ca}$ & 13.1 & 19.0 & 20.1 & 15.9 & 15.2 & 15.1 & 12.3 & 13.5 & 8.7 & 14.8 \\
\hline Mean & 14.6 & 14.5 & 19.9 & 15.2 & 13.1 & 13.5 & 10.8 & 9.9 & 9.8 & \\
\hline
\end{tabular}

${ }^{1}$ Each figure represents the computed mean of 3 replicates.

TABLE 5.-Mean specific-activity values for polyphenol oxidase from leaves of immature sugarcane supplied with decreasing nitrate, phosphorus, potassium, and calcium. in sand culture ${ }^{1}$

\begin{tabular}{|c|c|c|c|c|c|c|c|c|c|c|}
\hline \multirow{2}{*}{ Treatment } & \multicolumn{9}{|c|}{ Results with cane aged (weeks) - } & \multirow{2}{*}{ Mean } \\
\hline & 14 & 16 & 18 & 20 & 22 & 24 & 26 & 28 & 30 & \\
\hline Control & 12.9 & 15.0 & 16.3 & 14.3 & 13.9 & 13.4 & 12.1 & 13.1 & 15.0 & 14.0 \\
\hline$-\mathrm{NO}_{3}$ & 20.7 & 26.4 & 28.3 & 32.2 & 24.6 & 21.9 & 12.8 & 10.8 & 14.4 & 21.3 \\
\hline$-\mathrm{P}$ & 11.9 & 15.9 & 18.6 & 15.7 & 12.6 & 14.0 & 8.8 & 11.4 & 11.5 & 13.4 \\
\hline$-K$ & 24.8 & 26.6 & 30.4 & 26.0 & 22.8 & 24.2 & 19.5 & 18.1 & 18.1 & 23.4 \\
\hline$-\mathrm{Ca}$ & 16.1 & 21.3 & 23.0 & 18.3 & 17.0 & 15.4 & 12.6 & 17.3 & 11.1 & 16.9 \\
\hline Mean & 17.3 & 21.0 & 23.3 & 21.3 & 18.2 & 17.8 & 13.2 & 14.1 & 14.0 & \\
\hline
\end{tabular}

${ }^{1}$ Each figure represents the computed mean of 3 replicates.

Clearly some other mechanism than this was operative for the increased sucrose by low $\mathrm{K}$ and low Ca treatments.

Both polyphenol oxidase and peroxidase were greatly stimulated among plants receiving lower $\mathrm{NO}_{3}$ and $\mathrm{K}$ supply (tables 5 and 6 ). All nutritional treatments caused peroxidase increases. However, discrepancies between control and treatment enzymes, already apparent at 14 weeks, render this data unsuitable for further speculation. 


\section{SENSITIVITY OF AMYLASE TO NUTRIENT LEVEL}

Aside from the original objectives of this work an additional type of information was exemplified by the sensitivity of amylase to declining nutrient supply. The author has demonstrated in the past that enzymes might be used to advantage for the early detection of nutrient deficiencies in plants $(12,13)$. During the present study, as a further example, amylase reflected changes in nutrient supply almost as soon as the reductions were initiated (table 3). Visible $\mathrm{N}$ - and Ca-deficiency symptoms appeared at about 8 or 9 weeks, respectively, after the disorders had been forewarned by measureable changes in amylase behavior.

The enzyme-assay technique offers three distinct advantages over foliaranalysis and visible-symptom diagnosis: 1, An active fraction of total

TABLE 6.-Mean specific-activity values for leaf peroxidase of immature sugarcane supplied with decreasing nitrate, phosphorus, potassium, and calcium in sand culture ${ }^{1}$

\begin{tabular}{|c|c|c|c|c|c|c|c|c|c|c|}
\hline \multirow{2}{*}{ Treatment } & \multicolumn{9}{|c|}{ Results with cane aged (weeks) - } & \multirow{2}{*}{ Mean } \\
\hline & 14 & 16 & 18 & 20 & 22 & 24 & 26 & 28 & 30 & \\
\hline Control & 22.1 & 22.0 & 21.6 & 21.9 & 20.4 & 15.4 & 15.2 & 19.2 & 24.2 & 20.2 \\
\hline$-\mathrm{NO}_{3}$ & 48.1 & 45.5 & 59.0 & 68.1 & 46.7 & 37.7 & 19.1 & 20.5 & 23.5 & 40.9 \\
\hline$-\mathrm{P}$ & 39.5 & 63.9 & 64.1 & 52.8 & 45.2 & 39.3 & 32.0 & 43.1 & 32.6 & 45.8 \\
\hline$-\mathrm{K}$ & 32.4 & 47.9 & 62.0 & 43.3 & 31.7 & 42.1 & 32.6 & 39.2 & 34.1 & 40.6 \\
\hline$-\mathrm{Ca}$ & 29.1 & 38.7 & 49.7 & 34.6 & 24.8 & 23.3 & 17.1 & 34.8 & 18.3 & 30.0 \\
\hline Mean & 34.2 & 43.6 & 51.3 & 44.1 & 33.8 & 31.6 & 23.2 & 31.4 & 26.5 & \\
\hline
\end{tabular}

${ }^{1}$ Each figure represents the computed means of 3 replicates.

nutrient content is being measured rather than gross content of both active and inert forms; 2 , the investigator is dealing with the "how" and "why" of plant nutrition simultaneously while visible symptoms plus much tissue-analysis data tell only "what" or "how much"; and 3, the investigator is immediately warned of specific biochemical areas involved in the nutritional disorder. In the instance of amylase, we know that polysaccharide hydrolysis is involved, with ramifications bearing directly upon sucrose synthesis.

\section{SUMMARY}

Deficiencies of nitrogen, phosphorus, potassium, and calcium were gradually induced in sugarcane grown by sand culture. There were three objectives: 1 , To determine whether nutritional stress in general is a means of inducing higher sucrose production; 2, to determine whether sucrose increases can be triggered without reaching nutrient-deficiency levels which 
would reduce tonnage; and 3 , to ascertain whether increased sucrose production can be traced to common behavior patterns of hydrolytic and oxidative enzymes. All plants received a moderately high level of all nutrients until 14 weeks of age. Thereafter, individual nutrients were gradually lowered at intervals of 2 weeks, while control plants continued to receive the original levels.

All plants subjected to nutritional stress accumulated higher leaf sucrose than control plants, regardless of the nutrient withheld. In each instance sucrose increases were recorded before nutrient supply had reached deficiency proportions. General nutritional stress thus appears to trigger variations in sugar level, with nutritional imbalance rather than actual deficiency being a critical factor. All plants under nutritional stress revealed a concurrent suppression of amylase as sucrose increased. Peroxidase was greatly stimulated by all nutritional treatments. Phosphatase was suppressed by decreasing nitrate and phosphorus, but was generally unaffected by the potassium and calcium treatments. Several distinct mechanisms of increased sucrose formation are indicated by the enzyme data. Sensitivity of amylase to changing nutrient supply is discussed from the standpoint of a possible indicator of approaching deficiency.

\section{RESUMEN}

En plantas de caña de azúcar cultivadas en arena se produjeron gradualmente deficiencias de nitrógeno, fósforo, potasio y calcio. Los objetivos eran tres: 1, Determinar si mediante un régimen de nutrición limitado puede inducirse una mayor producción de sacarosa; 2, determinar si es posible inducir estos aumentos de sacarosa sin alcanzar niveles de deficiencia nutrimental que reduzcan el tonelaje; y 3, investigar si el aumento en la producción de sacarosa se debe a los patrones corrientes de acción de las enzimas hidrolíticas y oxidantes. Las plantas recibieron todos los elementos nutritivos en concentraciones moderadamente altas durante las primeras 14 semanas de crecimiento. De ahí en adelante, y a intervalos de 2 semanas, se redujeron gradualmente las concentraciones de los distintos elementos nutritivos, mientras que las plantas testigos siguieron recibiendo los niveles originales.

Todas las plantas sometidas al régimen de nutrición limitado acumularon más sacarosa en las hojas que las plantas testigos, independientemente del elemento nutritivo que se redujo. En cada caso, los aumentos de sacarosa se obtuvieron antes de que se alcanzara un nivel de deficiencia de los elementos nutritivos. Por tanto, parece ser que un régimen de nutrición limitado, generalmente induce variaciones en el nivel de azúcar, siendo el factor responsable, más bien, el desbalance de los elementos nutritivos que la deficiencia en sí. Todas las plantas afectadas por el régimen de nu- 
trición limitado revelaron una disminución de la amilasa, a medida que la sacarosa aumentó. La peroxidasa se estimuló grandemente bajo todos los tratamientos. La fosfatasa disminuyó al reducirse el nitrato y el fósforo, pero en general no se afectó con los tratamientos de potasio y calcio. Los datos obtenidos acerca de las enzimas demuestran que son varios los mecanismos que inducen a un aumento en la formación de la sacarosa. Se discute el hecho de que la amilasa responde a los cambios en el nivel de los elementos nutritivos, desde el punto de vista de que pueda servir como señal de que se está llegando a un nivel de deficiencia.

\section{LITERATURE CITED}

1. Alexander, A. G., Sucrose-enzyme relationships in immature sugareane as affected by varying levels of nitrate and potassium in sand culture, J. Agr. Univ. P.R. 48(3): 165-231, 1964.

2. - Physiological studies of enzymes catalyzing the synthesis and hydrolysis of sucrose, starch, and phosphorylated hexose in sugarcane, J. Agr. Univ. P.R. 49(1): 60-75, 1965 .

3. - - Induction of varying sugar levels in leaves of immature sugarcane by use of acid phosphatase inhibitors, J. Agr. Univ. P.R. 49(1): 35-59, 1965.

4. - Behavior of enzymes governing starch- and sucrose-forming pathways in two sugarcane varieties supplied with variable nitrate and phosphate in sand culture, J. Agr. Univ. P.R. 49(2): 153-75, 1965.

5. - - Hydrolytic proteins of sugarcane: The acid phosphatases, J. Agr. Univ. P.R. $49(2): 204-8,1965$.

6. - - Hydrolytic proteins of sugarcane. Amylase, J. Agr. Univ. P.R. 49(3): 308$24,1965$.

7. - The oxidizing enzymes of sugarcane: Tyrosinase (polyphenol oxidase), $J$. Agr. Univ. P.R. 50(2): 113-30, 1966.

8. - - The oxidizing enzymes of sugarcane: Peroxidase, J. Agr. Univ. P.R. $50(1)$ : $36-52,1966$.

9. — - The biosynthesis of starch in sugarcane, Proc. I.S.S.C.T., XII Cong., San Jaun, P.R. (in press).

10. - Changes in leaf-sugar content and enzyme activity of immature sugarcane following foliar application of indole-3-acetic acid, 2,4-dichlorophenoxyacetic acid, and maleic hydrazide, J. Agr. Univ. P.R. 49(1): 1-34, 1965.

11. - - Effects of tungsten and molybdenum on sucrose content and hydrolytic enzymes of immature sugarcane, J. Agr. Univ. P.R. 49(4): 429-42, 1965.

12. - - Abnormal enzyme activity as an early indicator of approaching nutrient deficiencies in plants, Proc. Fifth Intnl. Colloquium on Plant Analysis and Fertilizer Problems, College Park, Md., 1966 (in press).

13. - - Effects of varying nutrient levels on growth and enzyme activity of cauliflower: Thesis submitted to the Faculty of the Graduate School of the University of Maryland in partial fulfillment of the requirements for the degree of Doctor of Philosophy, 1960.

14. Baver, L. D., Report of Committee in Charge of the Experimental Station, Hawaiian Sugar Planter's Association, p. 51, 1944.

15. Cardini, C. E., Leloir, L. F., and Chiriboga, J., The biosynthesis of sucrose, $J$. Biol. Chem., 214: 149-55, 1955. 
16. Roe, J. R., A colorimetric method for the determination of fructose in blood and urine, J. Biol. Chem. 107: 15-22, 1934.

17. Samuels, G., and Cibes-Viadé, H., Influence of mineral deficiencies on the growth and yield of sugarcane, J. Agr. Univ. P.R. $47(2): 61-75,1963$.

18. Sutherland, E. W., Cori, C. F., Haynes, R., and Olsen, N. S., Purification of the hyperglycemic-glycogenolytic factor from insulin and from gastric mucosa, $J$. Biol. Chem. 180: 825-37, 1949. 